\title{
FIVE CENTURIES OF REGIONAL DEVELOPMENT IN NORTHWEST GERMANY AND THE NETHERLANDS
}

\author{
Kees Terlouw \\ Urban and Regional research centre Utrecht \\ Faculty of Geosciences \\ Utrecht University \\ terlouw@geo.uu.nl
}

\begin{abstract}
Germany and the Netherlands have developed very differently over the centuries. A close examination of Dutch and German regions show the differentiated way in which regions profit from the changing developmental opportunities of the world-system. This article studies longterm regional development using regional urban population in the Netherlands and Northwest Germany. Initially the coastal regions profited from the emerging trade based agricultural worldsystem. Later on, state formation enabled some of the previously developed regions to regain their position. Industrialization concentrated the development. In recent times, development spreads, giving developmental opportunities to some previously disadvantaged regions that are well located and well-endowed to profit from the recent developments in the world-system.
\end{abstract}

\section{INTRODUCTION}

The world-system approach is mostly used to explain the differences in development between states. This paper applies the world-system approach to the development of regions in two countries which have from the start belonged to the world-system. The position of the Netherlands and Germany in the world-system has however changed considerably between the emergence of the world-system and the present.

The Netherlands and Northwest Germany belonged from the start to the world-system (Wallerstein 1974). Several types of important relations shaped this area from the early modern times. For instance grain exports from the German part facilitated the population growth of Dutch trade cities. Half the food for these urban populations was imported. Migration was also important. In the first half of the seventeenth century $39 \%$ of marriage partners in Amsterdam were born abroad. About half of the foreign born marriage partners in Amsterdam came from our study area. This migration declined in later centuries (Diederiks 1983: 330, 338). The significance of foreign migrants in Dutch cities was much greater compared to other European cities at the time. For instance Paris received a significant influx of foreign refugees in the end of the seventeenth century. However, even the by far largest group of Catholic Jacobite refugees from the British Isles amounted to only about 3\% of the Parish population (Genet-Rouffiac 1995). Our study area has also important seasonal migration. Up till the nineteenth century, seasonal labor in the Netherlands was a significant source of income for many marginal German regions. Although seasonal migration occurred also in other areas in Europe, the size and the international character 
of this phenomenon make our study area unique in Europe (Lucassen 1984, 1988). The trade relations between Germany and the Netherlands have also strongly influenced land use patterns. Nitz $(1989,1993)$ regards in the early modern period the Netherlands and North Germany as structured by a von Thünen like regional division of labor focused on the Amsterdam market, which especially transformed the agricultural land use in the areas which were most accessible for Dutch shipping. This was according to Nitz one aspect of the strong influence of the modern world-system on this area.

The area depicted in figure 1 is also interesting to study from a world-system perspective while the Netherlands and Germany have a very different but linked history. The trade based rise to hegemony by the Dutch in the seventeenth century contrasts with Germany's decline. Dutch traders dominated the trade in the world-system and the Dutch state achieved a prominent international position. Germany suffered in the same period from the Thirty Years War. This intensified a longer period of economic decline and caused the political fragmentation of Germany into numerous political entities. Urban population reflects these changes. In 1300 , both had comparable levels of urban densities. In 1700, the density in Germany had hardly changed, while in the Netherlands it increased nine fold. ${ }^{1}$ In the eighteenth century the influence of the Dutch state and economy declined as the French and especially the British improved their position in the world-system. In the nineteenth century the Dutch economy stagnated further. It tried to compensate for the decline in its economic competitiveness by intensifying the exploitation of its colonies in Asia (Indonesia). German unification and industrialization marked the rise from semiperiphery to a leading European core state, which started to dominate the European continent. This contrast between the Netherlands and Germany diminished after the defeat of Germany in two world wars and the industrialization of the Netherlands after the Second World War. Now the huge differences of the past have mostly disappeared.

The study area has a distinct regional structure. Three national cores dominate (See figure 1). The area between them is not a homogeneous peripheral space. In the South there is a zone with very fertile loess soil with old cities like Osnabruck, Hannover and Braunschweig. The coastal zone in the West and North profited from its sea trade possibilities and fertile clay soil. The more developed sea-based zone in the north and the land-based zone in the south are separated by a frugal zone. In this traditionally sparsely populated peripheral zone the infertile sandy soils dominate. Through this the Weser connects the sea-based zone with the land-based zone in the South. This regional differentiation from the coast in the West and North to the interior in the South and East makes it an interesting area to study the regional development over the different phases of the world-system. The stronger coastal and interior regions are not only separated by a frugal sandy zone, but are also divided by the border between the Netherlands and Germany with very different paths of development within the world-system.

\footnotetext{
${ }^{1}$ Data on urban population is quite scarce and quite fragmentary in the early modern era in this area (Diederiks 1983: 328). Data on urban population is based on Bairoch et al., (1988), the most comprehensive data set on urban population in Europe. This database covers much more cities than for instance de Vries (1984). Calculations are based on contemporary borders. Urban density is the number of people living in urban settlements per square kilometer. Urban settlements are those with more than 3000 inhabitants, as reported in Bairoch et al. (1988).
} 
Figure 1. The Study Area: National Cores, Regions and Urban Nodes (Full Names are Provided in the Appendix)

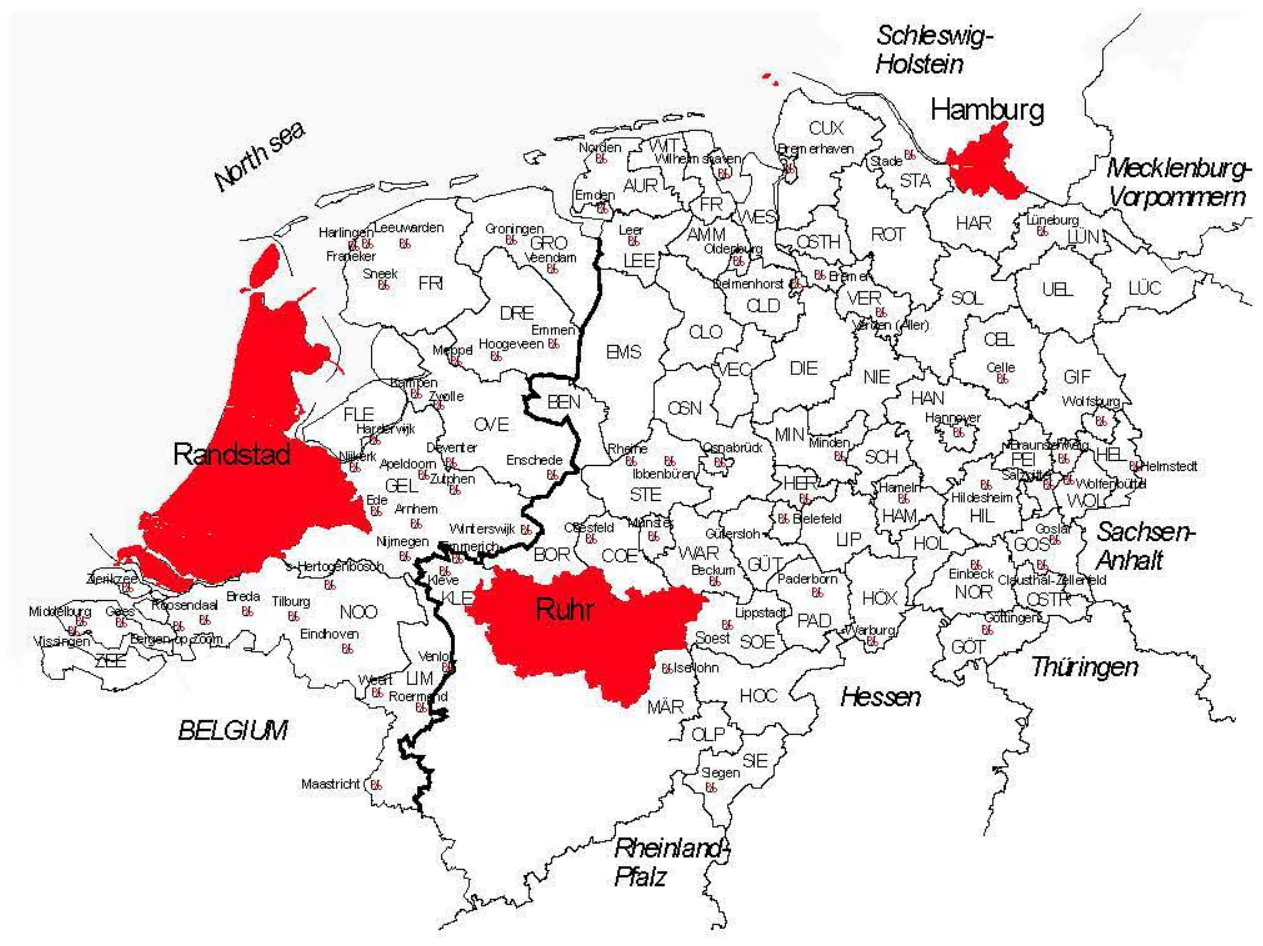

\section{THE DEVELOPING WORLD-SYSTEM}

Immanuel Wallerstein formulated the world-systems approach in the $1970 \mathrm{~s}$ as an alternative to state centered approaches to development. Both the then dominant modernization theory and Marxism equated state with society and studied social change from a state centered evolutionary perspective. Dependency theorist like Raúl Prebisch and André Gunder Frank criticized this and explained the lack of development in peripheral states through their unequal relations with core states. The world-system approach builds on this, but shifts the unit of analysis to the total network of these relations. This world-system has its own dynamic; it is more than its parts. The present world-system operates through a spatial division of labor through which the core exploits the periphery. The competition between rivaling states makes it possible for entrepreneurs to locate their different activities in areas where they can maximize their profits. The weak peripheral states enable them to produce cheap products, while in strong core states they can profit from political support to protect their more monopolistic business activities like financial services. The semi-peripheral states depolarize the world-system and are sometimes able to improve their position in the world-system. This rearrangement of states over the different positions in the world-system takes place especially during periods of economic crisis. These crises also result in the spatial (extensive) and social (intensive) expansion of the world-system. 
The modern world-system emerged in the sixteenth century in Europe and has expanded over the centuries to cover the whole globe (Wallerstein 1976, 1979).

In the sixteenth century, the core states in Northwest Europe profited from trade in agricultural products with Eastern Europe (grain and timber) and the Americas (gold, silver and sugar). This enabled their economies to concentrate on highly profitable industries. The development in peripheral state suffered from their specialization in agricultural commodities with low profit margins. The relations with Northwest Europe also hindered the emergence of an independent class of entrepreneurs and weakened the peripheral states (Wallerstein 1974).

After its emergence in the long sixteenth century $( \pm 1450-1650)$, our world-system stagnated. Production and trade diminished. Although regional self-sufficiency increased and the international division of labor contracted, the capitalist world-system did not disappear. The many wars in this period ( \pm 1600 -1750) strengthened the core states and institutionalized the interstate system of competing sovereign states. This consolidated the modern world-system and created the conditions for a renewed expansion in the next period, for instance by integrating their territories into national markets (Wallerstein 1980).

The revival of trade from the mid eighteenth century onwards signaled a period of renewed expansion of the world-system. It expanded and finally incorporated the entire globe at the end of this period $( \pm 1900)$. The military power of the European core states opened up new peripheries for the world-system in Asia and Africa. This spatial expansion went hand in hand with the further intensification of the world-system. The economic specialization and social polarization increased to such a degree that many characterized it as an industrial revolution. Although agriculture no longer dominated the economy and the role of wage laborers increased, there was no fundamental break in the functioning of the world-system. The membership of the core, semiperiphery and periphery changed in this period, but the working of the market based capitalist world-economy remained the same (Wallerstein 1989).

After its glorious nineteenth century, the world-system entered into a more challenging period. Economic stagnations and world wars characterized the first half of the twentieth century. The changing spatial division of labor characterizes the second half of the twentieth century. The European core states lost their dominant position in the world-system to new core states. The center of the world-system shifted further westward. The USA and later Japan overtook the West European economies. The more recent globalization further intensified integration and spreads semiperipheral development towards some parts of the former periphery, especially in Asia (Wallerstein 1976, 1979).

\section{THE WORLD-SYSTEM AND THE STUDY OF REGIONAL DEVELOPMENT}

This world-systems approach can help analyzing the linkages between worldwide and regional developments (Taylor 1988). However, in practice it hardly focuses on regions or cities. Although starting as a critique of state centered developmentalist thinking of modernization theories, states still dominate in Wallerstein's $(1974,1980,1989)$ voluminous analyses of our changing worldsystem. When occasionally the regional level comes into focus, it is mostly to explain the development of states. For instance, Wallerstein (1989a) compares French and British regional structure to explain why the British state triumphed in the nineteenth century. Some see this as a fundamental problem in the conceptualization of space in the world-systems approach. 
"Wallerstein's conception of global space is thus most precisely described as an inter-state division of labor: national state territoriality serves as the basic geographical unit of the world economy" (Brenner 2004: 51). But it can also be seen as a more practical empirical deficiency. The state level still predominates in academic studies. The availability of statistics limits the analysis of worldwide quantitative data for the more recent past to the state level (Terlouw 1992).

However, the long-term development of individual regions is frequently studied form a world-systems perspective. For instance Hanna (1995) analyzed how the over the centuries improving position of the USA in the world-system influenced the regional development of a national peripheral region. Space then is almost reduced to a place. The relation with higher scales dominates the analysis. The spatial context of similar regions receives little attention.

It is very difficult to do justice to all the temporal and spatial complications of the worldsystem in empirical research. The complexity of time, scales, space must be reduced. Using urban population size as a rough indicator of regional development and reducing the study area, this article tries to overcome some of the problems in analyzing the relation between regional change and worldwide developments.

Urban development is a good indicator of regional development. Cities reflect, as the crossroads of both small- and large-scale interaction, the regions' internal and external capacity for development (Gottmann 1947, 1969; Hall and Hay 1980; Hoekveld 1994; Kuznets 1968; de Vries 1984). The differences in developments between cities reflect the wider patterns of changing regional development within the world-system. Cities are important nodes in the worldsystem. Some contend that the world-system is increasingly organized by world-cities. Globalization has in the last decades transformed the importance of nation-states in regulating the world-system, giving more room to cities to organize economic networks (Taylor 2000). Whereas city size and importance in wider networks do not necessarily coincide (Stoob 1985), population change is the best indicator of the development of the position and economic prosperity of a town (Van der Wee 1988: 308-309). Cities are also less transitory than regions, and are the most important building blocks from which regions are constructed.

Selecting the units to measure regional development within this zone is not so obvious. Regions are not lasting entities, but are constantly created and destroyed (Paasi 1991). Regional development is not only a characteristic of a region, but also creates regions. It is most practical to start from the present administrative division. It is not practical to study the many hundreds of municipalities in the study area. The first meaningful regional levels above municipalities are provinces for the Netherlands and districts (Landkreise) in Germany. ${ }^{2}$ The exclusion of large German cities from this administrative framework creates problems for analyzing regional differentiation. Large cities and rural regions are not comparable units for studying regional

\footnotetext{
${ }^{2}$ At this level Dutch regional borders are quite constant (Mitchell 1980, CBS). In Germany these regional borders have greatly changed. For Niedersachsen the reconstructed data are available (NLS 1995). For Nord-Rhein-Westfalen these had to be recalculated. The population figures for the old Kreise in Westfalen (Reekers 1956) were transformed into the present Kreise. Old municipalities were usually in their entirety transferred to the new Kreise. The instances in which the municipal borders were redrawn never involved more than a few percentages of the area of the Kreise. As these are mostly sparsely inhabited areas outside villages, the error for population figures is much lower. The data on the national core regions is the sum of the provinces South Holland, North Holland and Utrecht for the Randstad (Mitchell 1980; CBS), Hamburg (SLH) as state, and the Ruhr area as the territory of the Kommunalverband Ruhrgebiet (Steinberg 1978, 1985).
} 
development. The adding the population of these self-governing cities to its neighboring regions tries to alleviate this problem. Lines from the edges of the common border to the center of the city delimit the parts of the territory of the self-governing cities that are allocated to its neighboring regions. Proportionally to the size of the divided area, the urban population is divided over its neighboring regions. The population of the Randstad and the Ruhr area are aggregated.

\section{THE SIXTEENTH CENTURY}

Figure 2. Regional Development in the Sixteenth Century ${ }^{3}$

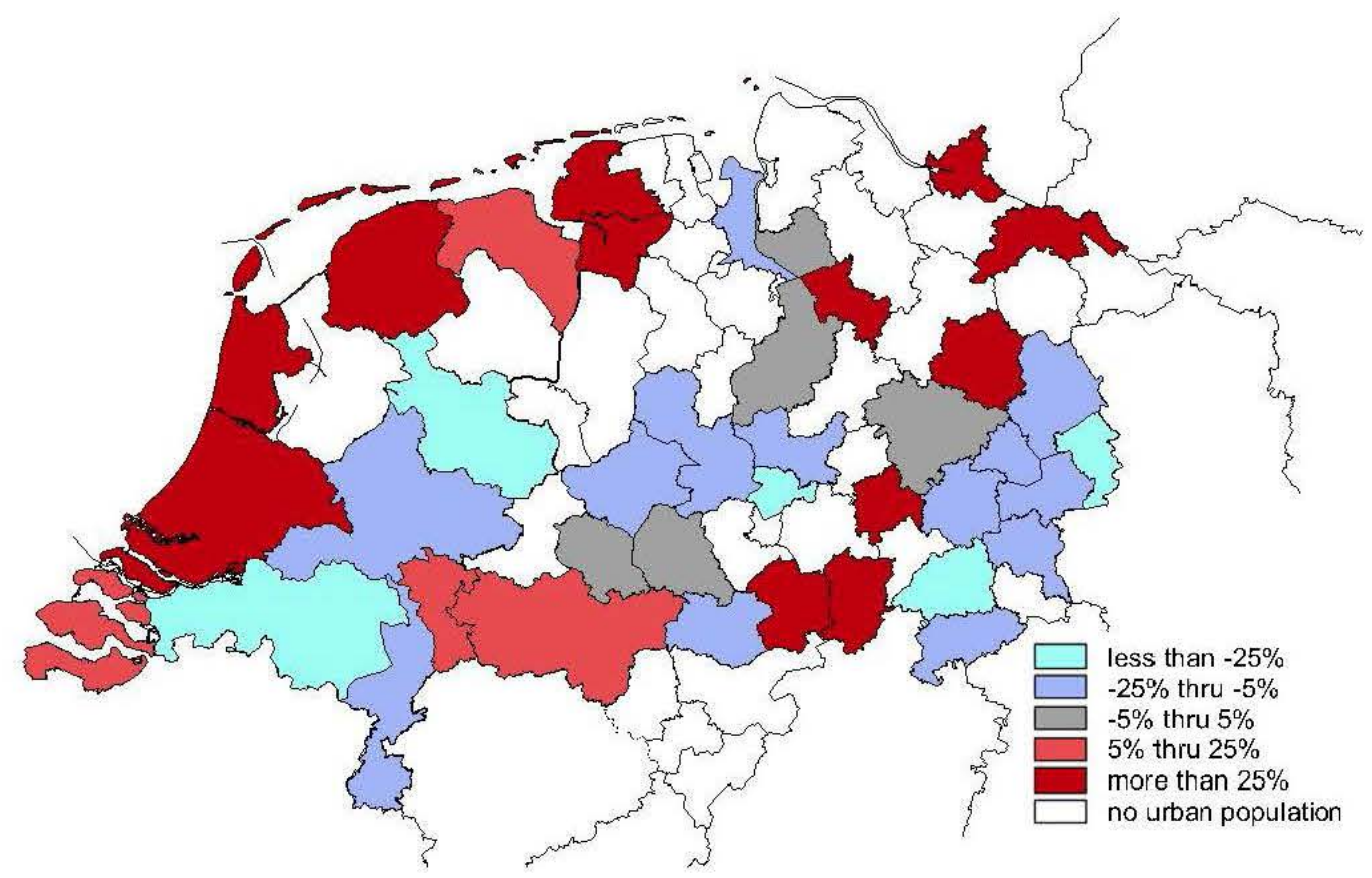

Figure 2 shows the changes in urban population for the regions in the Netherlands and Northwest Germany between 1500 and 1600 . The growth of the coastal regions and the relative decline of most of the inland regions is the dominant pattern of regional development in the sixteenth century. This contrasts with the medieval pattern which was dominated by the cities in the zone with fertile loess soils in the Southeast of the study area. Regional diversity in Medieval Europe was based on the locally different ecological possibilities for subsistence farming. Political power

\footnotetext{
${ }^{3}$ The aim of these maps is to depict the development of individual regions. In order to make comparisons possible of the pattern of regional development between the different periods the same classification procedure of regional development is used. For each year the proportion of the urban or regional population in the total population of the study area was calculated. The maps depict the percentage change in that century. (The overall growth in urban population in the study area was $14 \%$ in the $16^{\text {th }}, 19 \%$ in the $17^{\text {th }}$, $62 \%$ in the $18^{\text {th }}, 333 \%$ in the $19^{\text {th }}, 217 \%$ in the $20^{\text {th }}$, and $154 \%$ for the total population in the $20^{\text {th }}$ century).
} 
was mostly local, and based on forced surplus extraction. Urban associations regulated crafts and trade. The capitalist world-system which emerged in the long sixteenth century transformed these structural characteristics of 'feudal' Europe. It undermined the position of the cities in the interior.

The rise of the trade based coastal regions is very visible in the sixteenth century. The limited success of the uprising against the Hapsburg rulers further polarized this pattern of regional development. The inland regions of the Netherlands suffered from the initial defeats of the Dutch revolt against the Hapsburg rulers. After the defeat of the uprising in Flanders, many merchants and workers fled to other port cities along the shores of the North Sea. This migration affected not only the nearby Dutch provinces of Zeeland and Holland, but its influence extended all the way to Hamburg. After the fall of Antwerp in 1585, Flemish refugees formed a quarter of its population (Möller 1999: 25). Emden, a German port city facing the Dutch province of Groningen, profited even stronger from these refugees. These refugees fuelled a strong, but short period of prosperity. Between 1530 and 1570 its population increased from 4.000 to almost 20.000. Dutch refugees formed then a third of Emden's population (Brandt et al. 1994: 205). Emden based ships briefly dominated the Dutch grain trade with the Baltic at the end of the 1560s. Between 1565 and 1569 the number of Emden based ships passing through the Sound increased from 152 to 542, while the number of Amsterdam based ship declined from 504 to 139 (Brandt et al. 1994: 199). After the later successes of the Dutch revolt, the Dutch registered ships regained and increased their hold on the Baltic trade. Especially the blockade of Emden by the Dutch navy in 1574 forced the Dutch merchant to return. Most went to Amsterdam (Brandt et al. 1994: 200). One indicator of the intensity of this relation is that still in the seventeenth century $3.5 \%$ of all marriage partners in Amsterdam were born in Emden or its immediate vicinity. This was three times as many as the marriage partners from the much larger cities of Hamburg and Bremen and about a tenth of the total number of foreign born marriage partners $(39 \%)$ in Amsterdam (Diederiks 1983: 339).

\section{THE SEVENTEENTH CENTURY}

Emden's decline deepens in the seventeenth century. Figure 3 shows that it is one of the few examples where the regional development in the seventeenth century was different from the previous century. In general, regional development in the seventeenth century is an elaboration of the previous century but very distinct from subsequent centuries. In the seventeenth century the decline in most German regions deepens, while the Dutch dominance intensifies. The Dutch merchants not only controlled the trade on the North Sea and the Baltics, but also achieved a dominated position in more distant trade. The role of Dutch merchants and pirates in the transatlantic trade increased in the first part of the seventeenth century. Especially merchants from Zeeland played an important role in the slave trade. The Dutch merchants had also profitable trade links with Southeast Asia. Asia was then still outside the world-system, while the European did not control the local economy (Wallerstein 1974). 
Figure 3. Regional Development in the Seventeenth Century

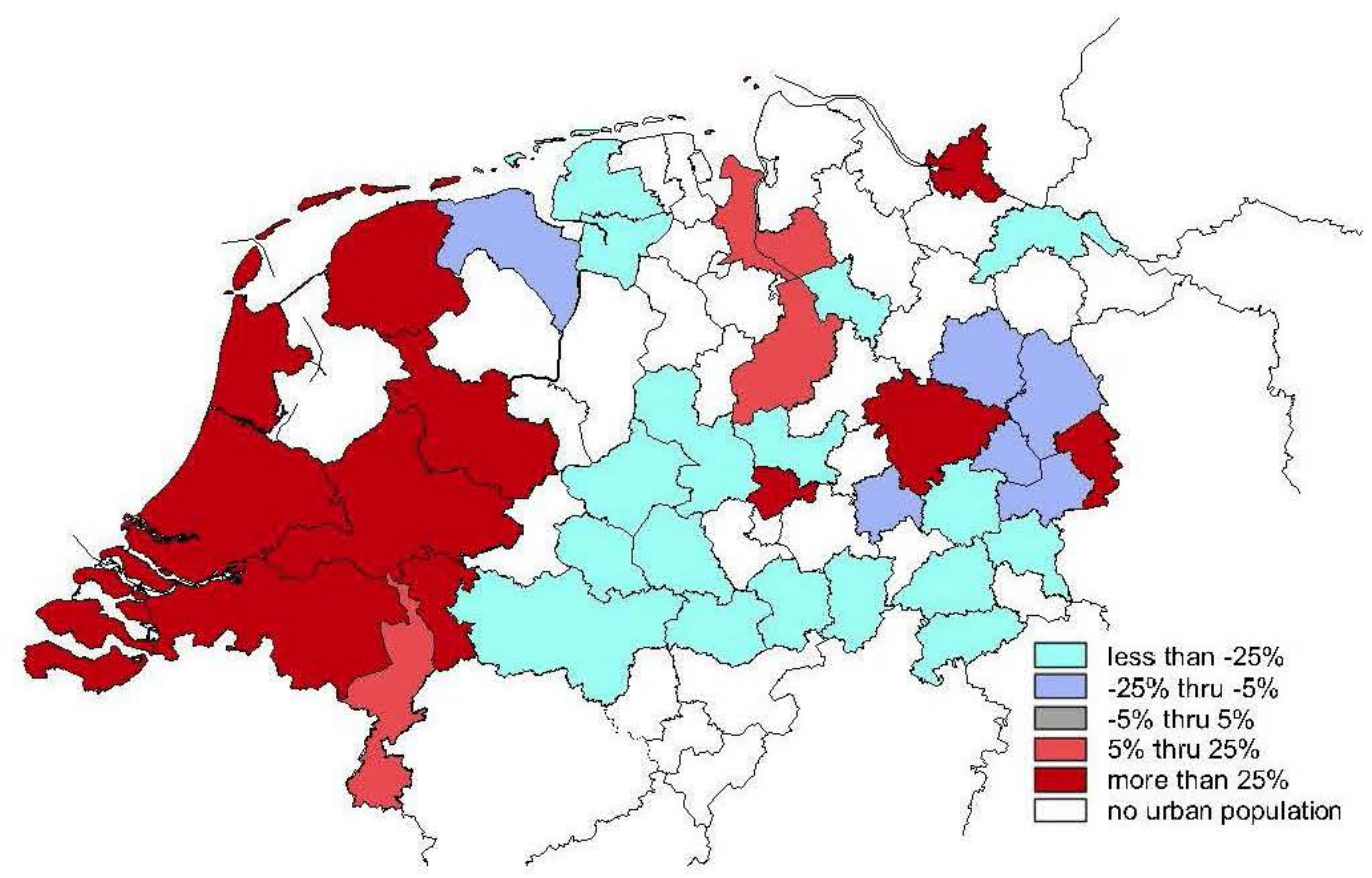

Regional development spread in this century from Holland to most other Dutch regions. The inland spread of development from the Dutch coastal zone reflects territorial consolidation of the Dutch state in their struggle against the Hapsburgers. It also indicates the Dutch rise to hegemony in the world-system. On the other hand, the decline of the German inland trading cities intensified during the Thirty Years War. Destruction of buildings, depopulation and desertion by long distance traders reduced towns like Hildesheim, Siegen and Einbeck for a long time to agricultural settlements within the old city walls (Kaemling 1995: 69, Hucker et al. 1997: 260). The Dutch controlled sea based trade replaced the old hanseatic network. The inland old hanseatic trading towns also lost their political autonomy. The Thirty Years War not only destroyed many cities, but also their political autonomy. The growth of the capital region of Hannover, one of the new territorial states emerging after the Thirty Years War, reflects this changing political situation.

However, a few old hanseatic towns like Hamburg and Bremen prospered. Maritime shipping was an important structuring element of the emerging world-system. This gave opportunities to some, but not all seaports to develop. Which seaport flourished depended also on specific factors, like location and especially political factors. Emden was too close to Holland. It was more a potential competitor in the same network, while Hamburg was more a distant ally which extended the Dutch trading network. During the Hanseatic League, Hamburg was Lubeck's outport to the North Sea. The emerging world-system reduced Lübeck to Hamburg's outport to the Baltic (Stoob 1995: 364). Hamburg profited from the revolt in the Low Countries at the end of the sixteenth century. It benefited from the influx of merchants and workers. After the fall of Antwerp in 1585, they formed a quarter of its population (Möller 1999: 25). Hamburg had in 1500 the same population (15.000) as Amsterdam. Both three doubled their population in the 
sixteenth century, due to refugees and the developing North Sea trade. They operated however in very different contexts. Amsterdam was part of a developing regional urban network spreading across Holland, which it increasingly dominated. It was also the staple port of trade with the Baltic, the America's and Asia. Hamburg did not profit from these trade links with the all parts of the world-system. It had a more isolated position. Its development mirrored the disintegration around it. Hamburg was an important refuge for Germans fleeing the destructions of the Thirty Years War. In the seventeenth century, the population growth of Amsterdam accelerated from 54.000 to 200.000 , while the growth of Hamburg slowed from 40.000 to 70.000 (Bairoch et al. 1988). Hamburg became a subordinate node in the Amsterdam centered trade network.

There emerged in the seventeenth century a von Thünen like division of labor focusing on the Amsterdam market (Nitz 1989, 1993). Accessibility to the Amsterdam market depended not only on distance, but also on water transport. In Germany, the Dutch centered division of labor integrated the regions along the Weser and the Leine as wheat export zones. The regions without urban population were not unaffected by the new spatial division of labor in the world-system. This was not just a zoning of land use, but also a spatial division of labor connecting social classes in different zones. Some agricultural unproductive regions became labor pools for nearby commercial agricultural regions and developing cities since the seventeenth century (Lucassen 1984). The Hümmling in the Emsland was one of those regions in the western part of the frugal zone characterized by seasonal labor migration. The agriculture in these regions was unimportant for the functioning of the world-system. Their role in the world-system was based on their cheap labor as semi-proletarians. Their too meager subsistence farming forced them to sell their labor cheap. They could survive on lower wages than the more fully proletarianized urban labor force because they had other sources of food through their subsistence farming. This was the basis for seasonal labor migration and a home industry.

Political expediency also helped the development of some German regions. The Dutch protected their borders with allies. At the North Sea coast, Emden even had a Dutch garrison. Part of the Ruhr area belonged to Kleve, which was for some time controlled by the Dutch and later taken over by the Dutch ally Brandenburg (Prussia).

This dominance of the Dutch in the emerging world-system was the result of the successful resistance of Dutch merchants to attempts of the Hapsburgers to centralize political control and create a world-empire. Their defeat gave room to the emerging world-system to develop, and gave the Dutch in the beginning of the seventeenth century hegemony (Wallerstein 1974). The regional development in our study area reflects their hegemony and a new economic division of labor based on the growing trade of agricultural products favoring coastal regions. 


\section{THE EIGHTEENTH CENTURY}

\section{Figure 4. Regional Development in the Eighteenth Century}

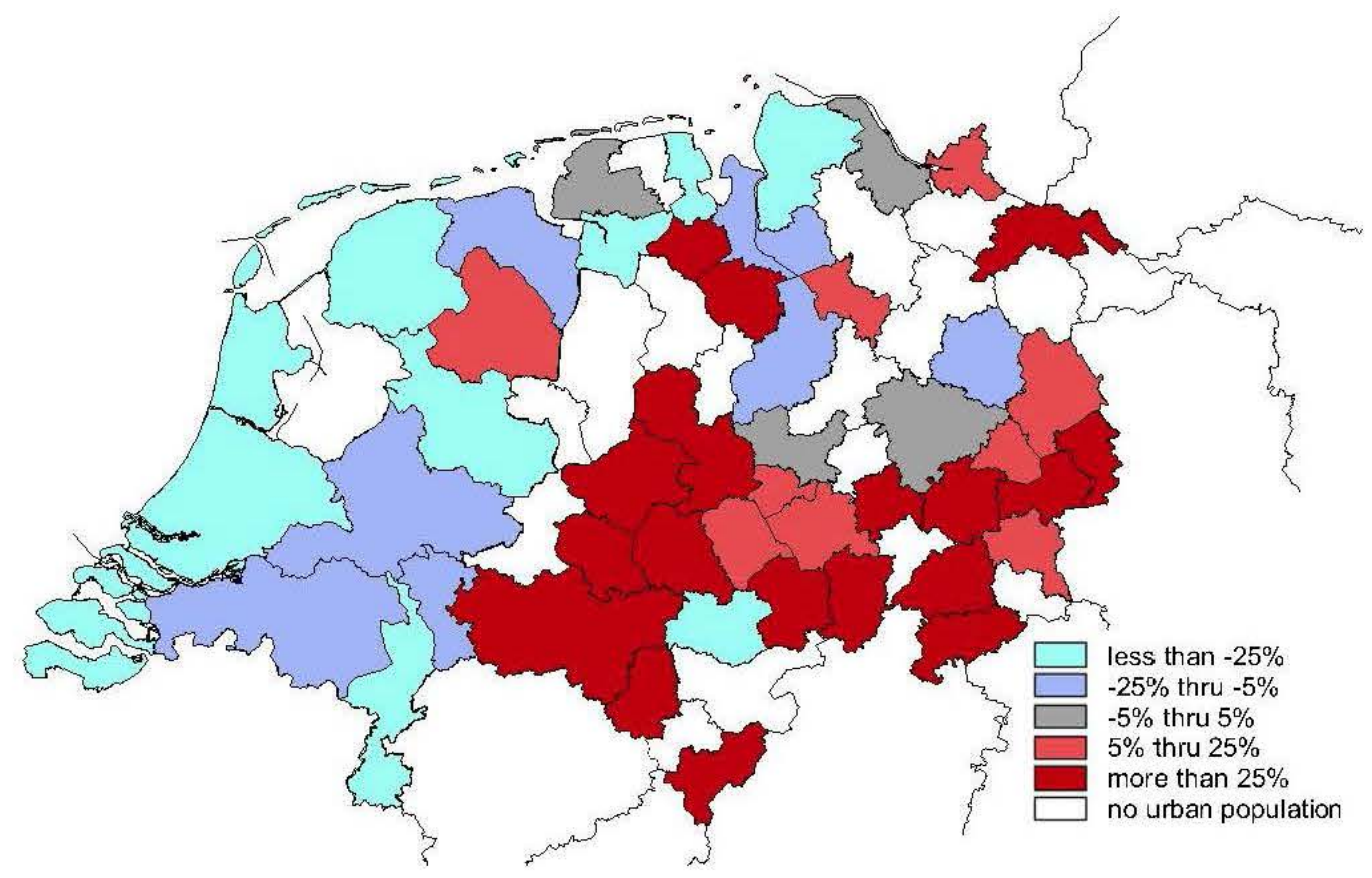

The pattern of regional development in the eighteenth century (figure 4) is almost the opposite of the previous centuries. With the exception of the continued decline of the regions near Emden, the persistent development of Hamburg and the rise of Oldenburg, the regional development in the eighteenth century is the reverse image of the seventeenth century. The loss of hegemony resulted in stagnation and decline in especially the sea-based regions in the Netherlands. This reflects the declining importance of Dutch merchants in long-distance trade networks, which in this century became increasingly dominated by the British. In contrast, German regions gradually recovered from the destructions of the Thirty Years War. Many old hanseatic towns, depopulated in the previous period, became once again urban centers.

The emergence of strong rivaling territorial states characterizes this period (Wallerstein 1980). Their rivalry fuelled the development of market forces which are outside the control of individual states. The international division of labor in the world-system regulates the production of the resources states need to compete. Successful states improved their economic control over their territories in their pursuit for resources to compete with other states. Their rivalry limited the scope of their success, but helped the creation of national markets. This further institutionalized the world-system, and changed the pattern of regional development.

The Dutch Republic based on an urban alliance of merchants had been effective in the struggle against the imperial ambitions of the Hapsburgers. The treaty of Westphalia of 1648 formalized the Dutch victory over the Hapsburgers, and was an important milestone in the Europe 
wide development toward the modern state based on territorial sovereignty (Wallerstein 1974, 1980). The Dutch Republic based its state formation on the wealth of its merchants. When the agriculturally based international division of labor stagnated and interstate rivalry intensified, the Dutch state lost out to states with more resources. Large territorial states performed better in this period with economic stagnation and increased rivalry. By increasing their control from the center, they not only extracted additional resources from their large territory through coercion, but also created a large national market, which provided new spaces for capitalist development (Tilly 1990, Braudel 1986: 277-385).

Although Germany was late in developing a united territorial state, the general political situation in Germany improved in this period. German states like Hannover, Oldenburg and Prussia became more effective, expanded their territories, and later on increased their economic cooperation. This development toward German unity helped the regional development of all German regions, but Prussian territories profited the most. Prussia's rise was an essential element in this integration process. The territories under its control profited from the expanding modern Prussian state that needed and helped economic development. This contrasted with neighboring German territories, which generally had a more conservative and anti-industrial agricultural regime based on landed gentry (Seedorf and Meyer: 1996).

The world-system wide economic stagnation in the eighteenth century shaped the regional development in this period. The sea-based regions lost ground to the land-based regions that profited more from the growth of territorial states and national markets.

\section{THE NINETEENTH CENTURY}

The world-system expanded again in the nineteenth century until it covered the whole world at the end of this century. It expanded not only into new territories, but also market forces penetrated new parts of society (Wallerstein 1989). In this century the Dutch state expanded its control over its colonies. Especially its Indonesian colony became an important source for cheap imports. This colony also attracted Dutch migrants although North America was a more popular destination. German migration to North America also increased strongly in this period (Therborn 1995, 42).

Industrialization shaped the regional development in this period as depicted in figure 5. The growth in the Ruhr area dominates the regional development. Prussian sponsored industrialization in an integrating Germany made this an important core state in the world-system. Prussian lead German unification also helped the rise of other German regions with favorable conditions for development in this period. Urban centres and large scale infrastructure, like harbors and railways, generated a pattern of regional development in Germany concentrating on a few core regions. This German pattern of development contrasts with the general decline in the Netherlands.

British hegemonic decline and the growing rivalry in the international political system enabled Prussia to integrate Germany. The Prussians transformed the British pioneered industrial development. The interventionist Prussian state sponsored close linkages between banking and industry, supported large-scale industrialization, and transformed the Ruhr area into an integrated industrial region. Not only coal mining and the steel industry linked up, but also the steel industry became functionally integrated with machine building and chemical industries (Terlouw 2003). 
Figure 5. Regional Development in the Nineteenth Century

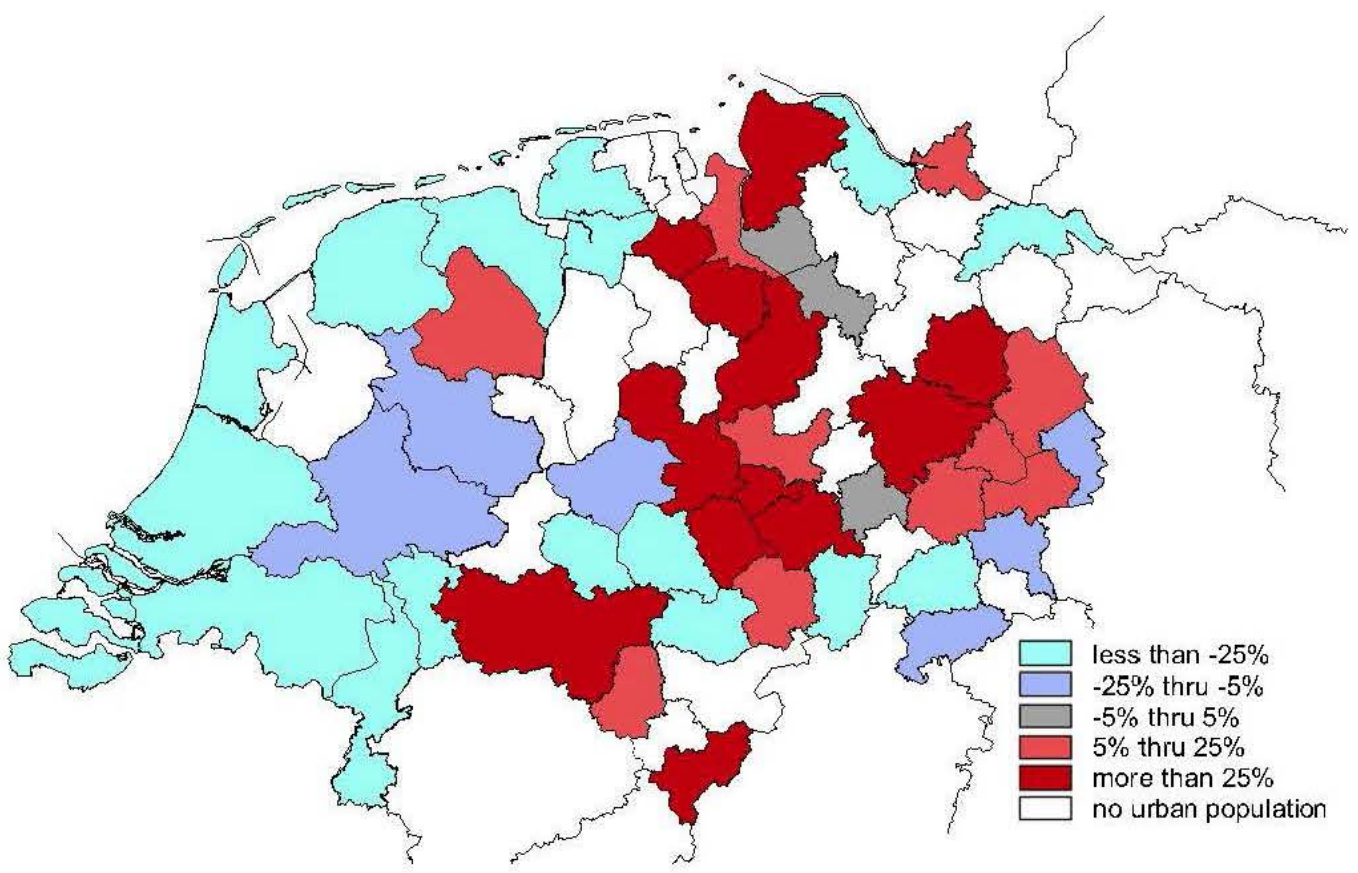

The economics of scale created a concentrated pattern of regional development in this period. Although the Ruhr area dominated, Prussian lead German unification also supported development in other urbanized regions. This includes the heartland of the kingdom of Hannover conquered by Prussia in 1866. The Prussians dislodged the conservative land-based regime with the modern expansionist Prussian administration. Annexation by Prussia freed Hannover also from the burdens of a small German state and opened a wider national market in which they had a central location. Hamburg, the other national core in the study area, continued to develop. With its good harbor and connections to the hinterland, it profited from the integration of the German national market and the growing overseas trade of Germany. Its urban mass also attracted industrialization. Bremen's development was similar, but not so concentrated. It was not only smaller, but its shallow harbor forced it to create a new harbor at the coast in Bremerhaven. Together with the other new Prussian navy port Wilhelmshaven this dispersed the regional development over the Weser estuary.

The pattern of regional development of the nineteenth century builds on that of the eighteenth century. The decline of Dutch regions continued. Only the sparsely populated province of Drenthe became less marginal. The different fortunes of the two nation states dominate the overall pattern of regional development in these centuries. Within Germany the eighteenth century was a period of recovery, while the nineteenth century showed new patterns of regional development focused on a few centers of industrialization. 


\section{THE TWENTIETH CENTURY}

\section{Figure 6. Regional Development in the Twentieth Century}

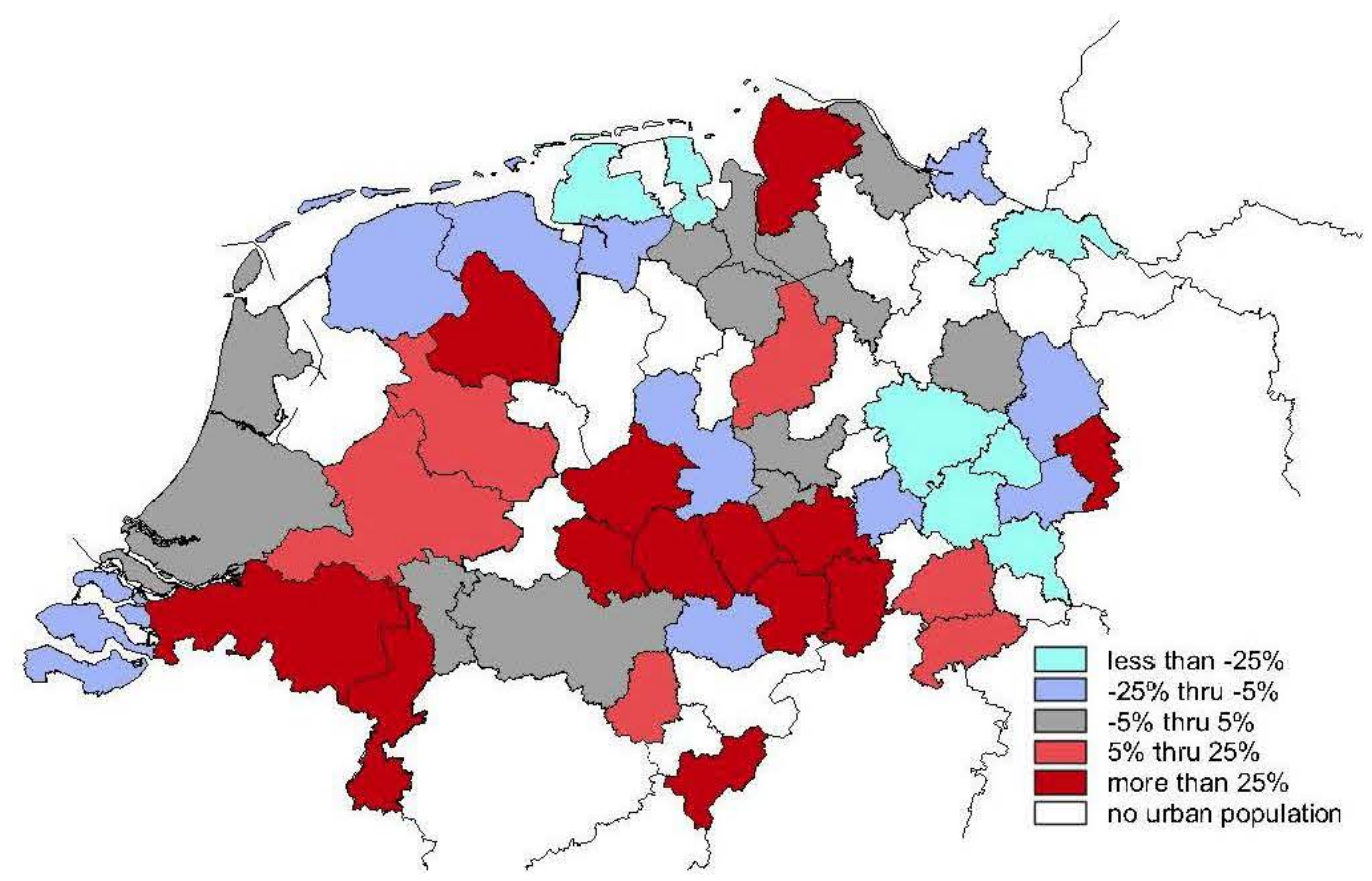

The pattern of regional development in the twentieth century is roughly the opposite of the previous centuries. The spread of development contrasts with the previous concentrated industrialization. This spread of development takes place at different scales. The Dutch state reentered the core of the world-system after centuries of stagnation. Many other former peripheral and semi-peripheral states improved their position in the world-system in the twentieth century (Terlouw 1992, 2002). As globalization, it now threatens the competitiveness of the industries in the old core states.

This spread of development from core to (semi-)periphery also characterizes regional development at sub-national state level. Figure 6 shows this. In addition we included figure 7 which is based not on the urban population, but on the total population for which there are only data for this period. This enables us to have a more detailed look at the regional development in this period. Figure 7 shows the rise of the border regions. This reflects the changing role of the German and Dutch states in regional development. At the regional scale, the influence of the nation state clearly diminishes in the unifying Europe. The border has lost its negative influence on regional development within the European Union. The further economic integration of the world-system gave developmental opportunities to new regions. Technological innovations, diminishing transportation and communication costs, enabled companies and commuters to become more footloose. This gave opportunities to new locations outside the national cores. The problems accompanying development accumulating in the core regions make them less attractive for housing and businesses. The inertia in the core regions generates an outward search for 
flexibility (Dodgshon 1998: 190-198). Figures 6 and 7 show the growth of many regions close to urbanized core regions.

\section{Figure 7. Regional Development in the Twentieth Century: Total Population}

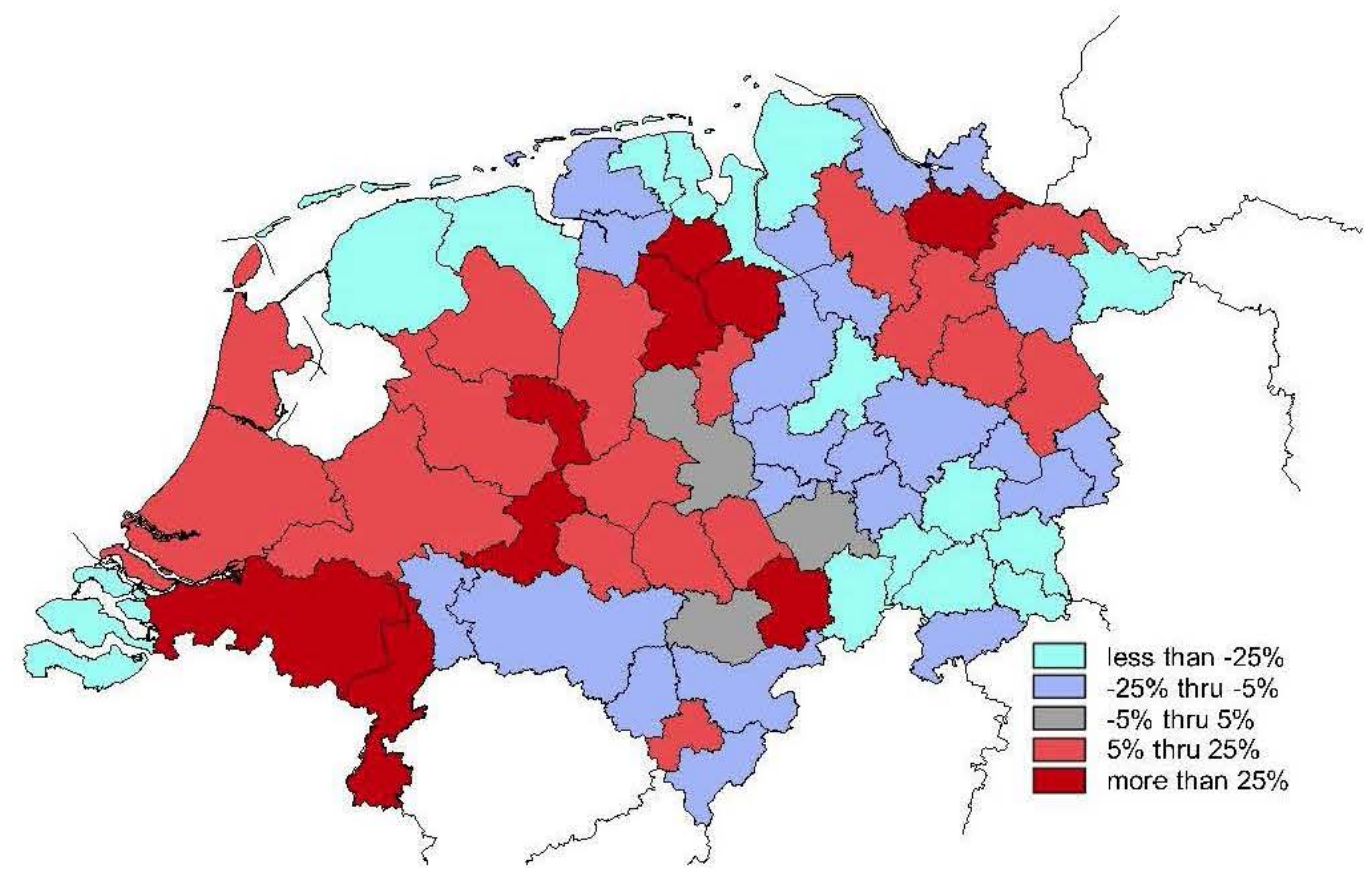

However, development spreads not to all surrounding regions. Intrinsic qualities of a region, like landscape, settlement structure and social climate, increasingly determine the developmental potential of regions. The calculable production potential of a region has lost much ground to perceived consumption possibilities. Agriculture no longer dominates rural economies, but influences indirectly the quality and intensity of subsequent regional development. The idyllic landscapes it has produced can make it very amenable for new developments. The traditionally less well-off agricultural regions with infertile sandy soils have diverse small-scale landscapes, free space, low land prices, and a social structure more open to new developments. On the other hand, a long history of intensive commercial agriculture produces unattractive monotonous largescale landscapes. Areas with fertile clay soils along the coast and with loess soils at the feet of the more mountainous areas in the southeast developed in the past on this basis. These specialized large-scale production landscapes contradict nowadays the imagery of an original landscape that suits the leisure and identification needs of the new middle classes. This layer of previous development hinders future developments (Massey 1984; Lamb 1975; Murdoch and Day 1998).

The twentieth century is characterized by a spread of development in different forms and at different scales. This gives new opportunities to previously underdeveloped regions whose success is still linked to historically formed characteristics. 


\section{CONCLUSION}

This article demonstrated that the world-systems approach is suitable to analyze long term regional development. The developments in the world-system generate distinct phases with very divergent patterns of regional development. Neither the emergence of the world-system in the sixteenth century, nor the subsequent new phases of development, including the recent phase of globalization homogenizes space.

The creation of the world-system generated a new pattern of regional development. The coastal regions benefited from the general increase in sea trade. They also profited from their relative inaccessibility of the Dutch coastal regions over land for armies. This was a crucial factor in the struggle between local merchants and the Hapsburgers, who tried to control the emerging capitalist world-system and transform it into a world-empire. In the seventeenth century this struggle between the Dutch and the Hapsburgers became part of a wider European power struggle. The economic and naval superiority sheltered the Dutch territory from the military destructions of the seventeenth century. In contrast, many inland German regions were destroyed during the Thirty Years War. However, the small and decentralized Dutch state later lost out to the larger European territorial states. The eighteenth century was beneficial for the emerging German territorial states. The subsequent process of German unification and industrialization further favored urbanized German regions in the nineteenth century. In the twentieth century regional development became more diversified. Regional development spread out from the old centres and the importance of national paths of regional development diminished. Specific regions, for instance previously hindered by their border location or having specific amenities, profited from new developmental opportunities.

\section{REFERENCES}

Bairoch, Paul, Jean Batou and Paul Chèvre. 1988. The Population of European Cities: Data Bank and short Summary of Results. Genève: Droz.

Bairoch, Paul. 1988a. Cities and Economic Development: from the Dawn of History to the Present. Chicago: The University of Chicago Press.

Brandt, Klaus, Hajo van Lengen, Heinrich Schmidt and Walter Deeters. 1994. Geschichte der Stadt Emden von den Anfängen bis 1611. Leer: Verlag Rautenberg.

Braudel, Fernand. 1974. Capitalism and Material Life: 1400-1800. London: Fontana.

Braudel, Fernand. 1986. The Perspective of the World: Civilization and Capitalism 15th-18th Century. New York: Harper and Row.

Braudel, Fernand. 1990. The Identity of France : Volume Two, People and Production. London: Fontana.

Brenner, Neil. 2004. New State Spaces: Urban Governance and the Rescaling of Statehood. Oxford: Oxford University Press.

CBS. Regional Statistics. Voorburg: Centraal Bureau voor de Statistiek.

Diederiks, Herman. 1983. "Amsterdam 1600-1800: Demographische Entwicklung und Migration." In: Wilfried Ehbrecht and Heinz Schilling. Niederlande und Nordwestdeutschland: Studien zur Regional- und Stadtgeschichte 
Nordwestkontinentaleuropas im Mittelalter und in der Neuzeit. Köln: Böhlau Verlag, 328-346.

Dodgshon, Robert A. 1998. Society in Time and Space: a Geographical Perspective on Change. Cambridge: Cambridge University Press.

Genet-Rouffiac, Nathalie. 1995. "Jacobites in Paris and Saint-Germaine-en-Laye". In: Eveline Cruickshanks, Edward T. Corp (eds.) The Stuart Court in Exile and the Jacobites. London: Hambledon Press, 15-38.

Gottmann, Jean. 1947. De la Méthode d'Analyse en Géographie Humaine. Annales de Géographie 56: 1-12.

Gottmann, Jean. 1969. A geography of Europe. New York: Holt, Rinehart and Winston.

Hall, Peter and Dennis Hay. 1980. Growth Centres in the European Urban System. London: Heineman.

Hanna, Stephen P.. 1995. 'Finding a Place in the World-Economy: Core-Periphery Relations, the Nation-State and the Underdevelopment of Garett County, Maryland" Political Geography 14: 451-472.

Hoekveld, Gerard A. and Gerda Hoekveld-Meijer. 1994: The Regional Development of France: an Application of a Regional Geographic Methodology. In: C.P. Terlouw (Ed) Methodological Exercises in Regional Geography: France as an Example. Utrecht: KNAG, 23-62.

Hucker, Bernd Ulrich, Ernst Schubert and Bernd Weisbrod. 1997. Niedersächsische Geschichte. Göttingen: Wallstein Verlag.

Kaemling, Werner. 1995. Atlas zur Geschichte Niedersachsens. Braunschweig: Holtzmeyer Verlag.

Kuznets, Simon. 1968. Modern Economic Growth: Rate, Structure and Spread. New Haven: Yale University Press.

Lamb, Richard F.. 1975. Metropolitan Impacts on Rural America. Chicago: University of Chicago.

Lucassen, Jan. 1984. Naar de Kusten van de Noordzee : Trekarbeid in Europees Perspektief, 1600-1900. Gouda.

Lucassen, Jan. 1988. „Quellen zur Geschischte der Wanderungen, vor allem der Wanderarbeit, zwischen Deutschland und den Niederlanden vom 17. Bis zum 19. Jahrhundert". In: Ernst Hinrichs, Henk van Zon. Bevölkerungsgeschichte im Vergleich: Studien zu den Niederlanden und Nordwestdeutschland. Aurich, 75- 89.

Massey, Doreen. 1984. Spatial Divisions of Labour: Social Structures and the Geography of Production. Houndsmills: Routledge.

Mitchell, Brian R. 1980. European Historical Statistics 1750-1975. London: MacMillan.

Möller, Ilse. 1999. Hamburg. Gotha: Klett-Perthes.

NLS. 1995. Bevölkerung der Gemeinden 1821 bis 1993. Hannover: Niedersächsisches Landesamt für Statistik.

Murdoch, Jonathon and Graham Day. 1998. "Middle Class Mobility, Rural Communities and the Politics of Exclusion". In: Peter Boyle and Keith Halfacree Migration into Rural Areas. Theories and Issues. Chichester: Whiley, 186-199.

Nitz, Hans-Jürgen. 1989. "Transformation of old and Formation of new Structures in the Rural Landscape of Northern Central Europe during the 16th to 18th Centuries under the Impact of the early Modern Commercial Economy". BEVAS/SOBEG 58: 267-290. 
Nitz, Hans-Jürgen. 1993. "The European World-System: a von Thünen Interpretation of its Eastern Continental Sector". In: Nitz, Hans-Jürgen The early-modern World-system in Geographical Perspective. Stuttgart: Franz Steiner Verlag, 62-83.

Paasi, Anssi. 1991. "Deconstructing Regions: Notes on the Scales of Spatial Life" Environment and Planning $A$ 23: 239-256.

Pounds, Norman J.G.. 1990. An Historical Geography of Europe. Cambridge: Cambridge University Press.

Reekers, Stefanie. 1956. Westfalens Bevölkerung 1818-1955. Münster: Aschendorff Verlag.

Seedorf, Hans Heinrich and Hans-Heinrich Meyer. 1996. Landeskunde Niedersachsen, Band 2, Niedersachsen als Wirtschaftsraum und Kulturraum. Neumünster: Wachholtz.

SLH. 1981. Statistisches Jahrbuch 1981. Hamburg: Statistisches Landesamt der Freien und Hansestadt Hamburg.

Slicher van Bath, Bernard. 1978. Geschiedenis: Theorie en Praktijk. Utrecht: Het Spectrum.

Steinberg, Heinz Günter. 1978. Bevölkerungsentwicklung des Ruhrgebietes im 19. und 20. Jahrhundert. Düsseldorf: Düsseldorfer Geographische Schriften.

Steinberg, Heinz Günter. 1985. Das Ruhrgebiet im 19. und 20. Jahrhundert: ein Verdichtungsraum im Wandel. Münster: Selbstverlag der Geographischen Kommission für Westfalen.

Stoob, Heinz. 1985. Die Stadt: Gestalt und Wandel bis zum industriellen Zeitalter. Koln: Böhlau.

Stoob, Heinz. 1995. Die Hanse. Graz: Verlag Styria.

Taylor, Peter J.. 1988. "World-systems Analysis and Regional Geography". Professional Geographer 40: 259-65.

Taylor, Peter J. 2000. "World Cities and Territorial States under Conditions of Contemporary Globalization" Political Geography 19, 1: 5-32.

Terlouw, Kees. 1992. The Regional Geography of the World-System: External Arena, Periphery, Semiperiphery, Core. Utrecht: KNAG.

Terlouw, Kees. 1996. "A general Perspective on the Regional Development of Europe from 1300 to 1850" Journal of Historical Geography 22, 2: 129-146.

Terlouw, Kees. 2002. "The Semi-Peripheral Space in the World-System". Review 25, 1: 1-22.

Terlouw, Kees. 2003. "Semi-Peripheral Developments: from World-Systems to Regions". Capitalism Nature Socialism 14: 71-90.

Tilly, Charles. 1990. Coercion, Capital, and European states: AD 990-1990. Oxford: Blackwell.

Therborn, Göran. 1995. European Modernity and beyond: the Trajectory of European Societies 1945-2000. London: Sage.

Vries, Jan de. 1984. European Urbanization: 1500-1800. Cambridge, Mass.: Harvard University Press.

Wallerstein, Immanuel. 1974. The Modern World-System: Capitalist Agriculture and the Origins of the European World-Economy in the sixteenth Century. New York: Academic Press.

Wallerstein, Immanuel. 1976. "The Rise and Future Demise of the World Capitalist System". International Review of Sociology 12, 3: 171-213.

Wallerstein, Immanuel. 1979. The Capitalist World-Economy. Cambridge: Cambridge University Press.

Wallerstein, Immanuel. 1980. The Modern World-System II: Mercantilism and the Consolidation of the European World-Economy 1600-1750. New York: Academic Press. 
Wallerstein, Immanuel. 1989. The Modern World-system III: The second Era of great Expansion of the Capitalist World-Economy, 1730-1840s. New York: Academic Press.

Wallerstein, Immanuel. 1989a. "France: a Special Case? a World-systems Perspective". In: Eugene D. Genovese and Leonard Hochberg Geographic Perspectives in History Oxford: Blackwell: 144-157.

Wee, Herman Van der. 1988. "Industrial Dynamics and the Process of Urbanization and Deurbanization in the Low Countries from the late Middle Ages to the eighteenth Century: a Synthesis". In: Herman Van der Wee The Rise and Decline of Urban Industries in Italy and in the Low Countries. Leuven: Leuven University Press: 307- 381.

\section{APPENDIX}

$\begin{array}{ll}\text { AMM } & \text { Ammerland } \\ \text { AUR } & \text { Aurich } \\ \text { BEN } & \text { Bentheim } \\ \text { BOR } & \text { Borken } \\ \text { CEL } & \text { Celle } \\ \text { CLO } & \text { Cloppenburg } \\ \text { COE } & \text { Coesfeld } \\ \text { CUX } & \text { Cuxhaven } \\ \text { DIE } & \text { Diepholz } \\ \text { DRE } & \text { Drenthe } \\ \text { EMS } & \text { Emsland } \\ \text { FLE } & \text { Flevoland } \\ \text { FR } & \text { Friesland } \\ \text { FRI } & \text { Friesland } \\ \text { GEL } & \text { Gelderland } \\ \text { GIF } & \text { Gifhorn } \\ \text { GOS } & \text { Goslar } \\ \text { GÖT } & \text { Göttingen } \\ \text { GRO } & \text { Groningen } \\ \text { GÜT } & \text { Gütersloh } \\ \text { HAM } & \text { Hameln-Pyrmont } \\ \text { HAN } & \text { Hannover } \\ \text { HAR } & \text { Harburg } \\ \text { HEL } & \text { Helmstedt } \\ \text { HER } & \text { Herford } \\ \text { HIL } & \text { Hildesheim } \\ \text { HOC } & \text { Hochsauerlandkreis } \\ \text { HOL } & \text { Holzminden } \\ \text { HÖX } & \text { Höxter } \\ \text { KLE } & \text { Kleve } \\ \text { LEE } & \text { Leer } \\ & \end{array}$




$\begin{array}{ll}\text { LIM } & \text { Limburg } \\ \text { LIP } & \text { Lippe } \\ \text { LÜC } & \text { Lüchow-Dannenberg } \\ \text { LÜN } & \text { Lüneburg } \\ \text { MÄR } & \text { Märkischer Kreis } \\ \text { MIN } & \text { Minden-Lübbecke } \\ \text { NIE } & \text { Nienburg } \\ \text { NOO } & \text { Noord-Brabant } \\ \text { NOR } & \text { Northeim } \\ \text { OLD } & \text { Oldenburg } \\ \text { OLP } & \text { Olpe } \\ \text { OSN } & \text { Osnabrück } \\ \text { OSTH } & \text { Osterholz } \\ \text { OSTR } & \text { Osterode } \\ \text { OVE } & \text { Overijssel } \\ \text { PAD } & \text { Paderborn } \\ \text { PEI } & \text { Peine } \\ \text { ROT } & \text { Rotenburg } \\ \text { SCH } & \text { Schaumburg } \\ \text { SIE } & \text { Siegen-Wittgenstein } \\ \text { SOE } & \text { Soest } \\ \text { SOL } & \text { Soltau-Fallingbostel } \\ \text { STA } & \text { Stade } \\ \text { STE } & \text { Steinfurt } \\ \text { UEL } & \text { Uelzen } \\ \text { VEC } & \text { Vechta } \\ \text { VER } & \text { Verden } \\ \text { WAR } & \text { Warendorf } \\ \text { WES } & \text { Wesermarsch } \\ \text { WIT } & \text { Wittmund } \\ \text { WOL } & \text { Wolfenbüttel } \\ & \end{array}$

